\title{
Tamm Review: Light use efficiency and carbon storage in nutrient and water experiments on major forest plantation species
}

\author{
Timothy J. Albaugh ${ }^{a^{*}}$, Janine M. Albaugh ${ }^{b}$, Thomas R. Fox ${ }^{a}, H$. Lee Allen ${ }^{c}$, Rafael A. Rubilar ${ }^{d}$, Pierre \\ Trichet $^{\mathrm{e}}$, Denis Loustau ${ }^{\mathrm{e}}$, Sune Linder ${ }^{\mathrm{f}}$ \\ ${ }^{a}$ Virginia Tech Department of Forest Resources and Environmental Conservation, 228 Cheatham Hall, \\ Blacksburg, VA 24061, USA. \\ b JMA Consulting, Hillsborough, NC, USA. \\ ${ }^{c}$ ProFor Consulting, Cary, NC, USA. \\ ${ }^{d}$ Cooperativa de Productividad Forestal. Facultad de Ciencias Forestales, Universidad de Concepción. \\ Victoria 631, Casilla 160-C, Concepción, Chile. \\ e INRA, UMR ISPA, F-33140 Villenave d'Ornon, France. \\ ${ }^{\dagger}$ Swedish University of Agricultural Sciences (SLU), Southern Sweden Forest Research Center, SE-230 \\ 53 Alnarp, Sweden. \\ * Corresponding author at Virginia Tech Department of Forest Resources and Environmental \\ Conservation, 228 Cheatham Hall, Blacksburg, VA 24061, USA. Tel.: +1-919-451-7328. \\ E-mail addresses: Tim Albaugh@vt.edu (T.J. Albaugh), Janine.albaugh@gmail.com (J.M. Albaugh), \\ trfox@vt.edu (T.R. Fox), allen.profor@gmail.com (H.L. Allen), rafaelrubilar@udec.cl (R.A. Rubilar), \\ pierre.trichet@pierroton.inra.fr, (P. Trichet), denis.loustau@pierroton.inra.fr (D. Loustau), \\ Sune.Linder@slu.se, (S. Linder).
}




\section{ABSTRACT}

We used published data from nine sites where nutrient and water optimization studies had been installed in a $2 \times 2$ factorial design to determine maximum biomass production in response to a simple set of treatments. We tested for site and treatment effects on the relationships between stem, aboveground (stem, branches, foliage) and total (aboveground + roots) biomass production versus intercepted light (light use efficiency, LUE). We also estimated the additional carbon stored as a result of treatment. The sites were located in Australia (Pinus radiata), Brazil (Eucalyptus grandis $x$ urophylla), France $(P$. pinaster), the United States in Georgia and North Carolina (P. taeda) and Hawaii (E. saligna), Portugal (E. globulus), South Africa (E. grandis), and Sweden (Picea abies). We hypothesized that site, treatment and their interaction would significantly affect LUE; however, we rejected our hypothesis because stem, aboveground and total LUE were not affected by site or treatment. The stem, aboveground and total LUE values were $1.21,1.51$, and $0.85 \mathrm{~g} \mathrm{MJ}^{-1}$, respectively. The total LUE value was lower than that for stem and aboveground LUE because a different population was used for the analysis (only five of the nine sites had total production data), and the total LUE relationship had a zero intercept whereas the stem and aboveground LUE relationships had a negative intercept. The average amount of additional carbon that would be stored by the irrigation, fertilization, and fertilization plus irrigation treatments was 3.9, 6.8 and 13.4 $\mathrm{Mg} \mathrm{CO}_{2}$ equivalents ha- $\mathrm{yr}^{-1}$, respectively. These additional carbon storage estimates, based on the research studies with annual nutrient and water applications, were similar to results obtained in operational settings with less intensive nutrient applications.

\footnotetext{
Key words: carbon, growth efficiency, nutrient optimization, potential productivity.
} 
Introduction

Beginning in the 1970's, studies examining the interaction between nutrient and water

54 applications in forest plantations were installed in different regions (e.g. (Persson, 1980; Linder, 1987)).

55 These studies built on previous work demonstrating the importance of nutrients and water and their interactive effects (e.g. (Tamm, 1964; Ingestad, 1974)). The nutrient proportions needed for optimum

57 growth are similar across species (Ingestad, 1987; Knecht and Göransson, 2004), and these studies utilized this concept to design an experiment that could be installed across site and species to optimize nutrient and water availability and ultimately, determine maximum productivity. At the time, and still relevant today, there was concern that nutrients applied to forests might move offsite (Ingestad, 1977; Tamm, 1991); however, these studies utilized a method to provide the nutrients needed for optimum growth without offsite loss (Linder, 1995). A network of experiments was established, and the results from these studies laid the groundwork for a substantial portion of our current understanding of forest plantation ecophysiology (Ryan, 2013). At this point in time, only a few of these sites remain active, with the notable exception of the Flakaliden study, which continues to operate 30 years after the treatments were first applied; however, additional insight may still be gained from the work as a whole.

Resource availability in forest plantations influences foliage production, which in turn affects stand light interception and ultimately, stand growth (Linder, 1987; Vose and Allen, 1988; Cannell, 1989b; Landsberg and Sands, 2011). After a site has been selected and a stand established, forest managers are somewhat limited in their ability to manipulate available resources. The primary tools for influencing resource availability after stand establishment are managing nutrient and water availability. Nutrients may be added directly through fertilization (e.g. (Albaugh et al., 1998; Bergh et al., 1999)), and crop tree nutrient availability may be improved through vegetation control (e.g. (Hanna et al., 1999)). Vegetation control may improve water availability for the crop species (e.g. (Byrne et al., 1987)), and water can also be added directly (e.g. (Coyle et al., 2016)). The nutrient and water application studies examined the direct application of nutrients and water and quantified the response to treatment. As a result, annual production estimates, including stem, aboveground (stem, leaves, branches), and total (stems, leaves, branches, roots) production, and leaf area index or canopy light interception data were published from several sites. These data permit an examination of growth efficiency (GE: growth per unit foliage) and/or 
light use efficiency (LUE: growth per unit intercepted light) across site and species (Monteith, 1977;

81 Waring et al., 1981; Linder, 1985; Linder et al., In review). At individual sites, changes in GE were

82

83

84

85

86

87

88

89

90

91

92

93

94

95

96

97

98

99

100

101

102

103

104

105

106

107

observed, especially when examining total production, which likely occurred due to a shift in allocation where treatments with high resource availability resulted in less carbon allocation to the roots (e.g. (Albaugh et al., 1998)). In the literature, LUE analyses have been completed for aboveground production (Linder, 1985; Cannell, 1989a; Dallatea and Jokela, 1991; McMurtrie et al., 1994; Ahl et al., 2004; Landsberg and Sands, 2011) and for total production estimates (Cannell, 1989a; Runyon et al., 1994; Landsberg and Sands, 2011). However, an examination of LUE where site, and nutrient and water availability effects can be tested across a wide range of species has not been found for forest plantations.

Pioneering work quantifying light use efficiency in crop plants began in the 1970s (Monteith, 1977; Linder et al., In review). Prior to the development of this concept, researchers were able to observe how plants responded to various treatments but had limited ability to predict how the plants might respond. Light use efficiency focuses on the basic relationship of plant growth, where plants use the sun's energy (light) to fix carbon and then partition that carbon into various plant components (Cannell, 1989b). By quantifying light use efficiency, researchers had a tool they could use to observe how treatments would influence plant growth and from which they could develop mathematical models (e.g. MAESTRO (Wang and Jarvis, 1990) to help them predict how a plant might respond to a given treatment, a change in climate or a change in location (planted as an exotic). This work continues with efforts to calibrate and use remotely sensed estimates of LUE to estimate net primary productivity at a global scale (Waring et al., 1993; Running et al., 2000; Ahl et al., 2004; Running et al., 2004; Wang et al., 2004)).

The nutrient and water application studies were useful in refining the predictive abilities associated with the light use efficiency concept. To help make predictions as to how plants may respond to perturbations, the productive potential must be known. The nutrient and water application studies were designed to determine maximum productivity by eliminating nutrient and water limitations while permitting the determination of which of the two resources (nutrients or water) was the most limiting. For example, studies conducted in Australia, Sweden and North Carolina resulted in productivity rates that exceeded expectations or were not considered possible prior to study establishment (Raison and Myers, 1992; Bergh et al., 2005; Albaugh et al., 2009a). Similarly, nutrients were determined as the primary growth 
limitation in areas that were initially considered to be limited by other factors (e.g. cold temperatures in Sweden, drought in North Carolina). For a given species and site combination, an increase in LUE (more aboveground production for the same amount of absorbed light) would typically indicate an increase in canopy-scale photosynthesis or a change in allocation where more carbon is allocated to aboveground components.

In water-limited systems, irrigation permits photosynthesis to continue under dry conditions, whereas in the absence of additional water, plants reduce or stop photosynthesis (e.g. (Campion et al., 2006; Stape et al., 2008)). Irrigation allows plants to take advantage of more of the light they absorb to produce additional biomass. Similarly, improved nutrient availability resulting from fertilization may change allocation patterns such that more fixed carbon is allocated to aboveground components so that for the same amount of intercepted light, more aboveground biomass is produced (e.g. (Albaugh et al., 1998)). However, when observing total biomass production, allocation changes would likely be eliminated as a potential explanation for changes in LUE. In this case, additional hypotheses to explain changes in LUE include age-related decline, a phenomenon observed in many systems where older trees do not produce the same amount of biomass per unit of intercepted light as younger trees (Ryan et al., 1997; Ryan et al., 2004) and changes in the hydraulic morphology of fertilized trees, which would permit photosynthesis closer to the wilting point, without cavitation, resulting in greater biomass per unit of intercepted light (Ewers et al., 2000).

When examining species and sites under different resource availability conditions, changes in LUE may be influenced by differences relative to the specific environment in which the trees are growing. For example, Picea abies L. Karst. commonly grows in colder climates where low temperatures damage the photosynthetic machinery and soil may remain frozen such that in early spring when conditions are otherwise favorable, photosynthesis does not occur at the same rate as later in the year under similar conditions because the plant is repairing this damage or there is no available soil moisture for photosynthesis to occur (Bergh et al., 1998). Improved nutrient status reduces this effect and thereby, an increase in LUE would be observed with fertilization (Bergh et al., 1998). Similar phenomena have been observed in the coniferous forests of western North America where climatic and other environmental constraints have a large impact on light use efficiency across a range of species and sites; when 
adjusting for climatic constraints, however, a common LUE value was identified (Runyon et al., 1994). Water limitations are known to reduce photosynthesis across the spectrum of species and sites examined here; for example, in species that grow in environments where water limitations are severe (Eucalyptus in South Africa, Brazil and Australia), the response to increased water availability will be much greater compared to environments not limited by water. Both of these conditions (i.e. variations in water and nutrient availability) could result in a situation where the LUE across site and species would differ with the resources available to the species at a given site. With these studies in mind, we might hypothesize that analysis of LUE from the nutrient and water studies would indicate differences in LUE, where LUE would be higher with the addition of nutrients and water because these treatments have the potential to increase the amount of photosynthesis that would occur in response to a given amount of intercepted light.

Given the emphasis placed on sequestering carbon to mitigate climate change effects (IPCC, 2006), increasing the forest production area and the silvicultural intensity on forested land have been suggested as ways to increase carbon sequestration (Johnsen et al., 2001; Woodbury et al., 2007). Carbon emissions from forest fertilization (the carbon released as a result of the production, delivery and application of nutrients) were considerably lower than the amounts of additional carbon stored in Pinus taeda L. stands in the southeastern United States as a result of the fertilization (Albaugh et al., 2012), thus indicating the likelihood of an increase in carbon sequestration in fertilized stands of this species. The addition of water to forest land for irrigation purposes may be problematic given that climate change could result in some water-limited areas receiving even less water in the future; however, it would be interesting to know the potential trade-off between the additional carbon stored in irrigated stands and the additional water needed to produce that carbon (Albaugh et al., 2013).

Our interest was in examining data from the nutrient and water optimization studies to quantify LUE relative to aboveground (LUE-A), stem (LUE-S) and total (LUE-T) biomass production. Specifically, we tested the hypothesis that site (in this case a combination of species and location), fertilization and irrigation treatments and their interactions would influence LUE-A, LUE-S and LUE-T. Additionally, we wanted to determine the amount of additional carbon that would be stored in aboveground biomass if the nutrient and water optimization treatments were applied at a landscape scale.

\section{Methods}


We examined data from nine experiments where nutrients and water were applied to optimize

165

166

167

168

169

170

171

172

173

174

175

176

177

178

179

180

181

182

183

184

185

186

187

188

189

190

191

resource availability in a $2 \times 2$ factorial design (Table 1). The experiments were located in Australia (AU) at the Biology of Forest Growth Site (Raison and Myers, 1992), Brazil (BR) near Entre-Rios (Stape et al., 2008), France (FR) near Bordeaux (Trichet et al., 2008), the United States in Georgia (GA) near Bainbridge (Samuelson et al., 2004), in Hawaii (HI) near Hilo (Ryan et al., 2004) and in North Carolina (NC) at the Southeast Tree Research and Education Site (Albaugh et al., 1998), Portugal (PT) at the Furaduro Site (Pereira et al., 1994), South Africa (ZA) in KwaZulu-Natal (Campion et al., 2006), and Sweden (SE) at Flakaliden (Bergh et al., 1999). The species planted at each site were Pinus radiata D. Don (AU), Eucalyptus grandis x urophylla (BR), P. pinaster Ait. (FR), P. taeda (GA, NC), E. saligna (HI), E. globulus Labill. (PT), E. grandis (ZA), and Picea abies (SE). The treatments were a control (C, no additions), irrigation applied to eliminate water stress (I), fertilizer applied to eliminate nutrient limitations (F) and the combination of fertilization and irrigation (FI). The specific irrigation and fertilizer application amounts and timing differed for each study and can be found in the summary papers referenced earlier. However, the primary goal when applying the treatments at each site was the same: to eliminate water and nutrient limitations. When applied alone, fertilizer was broadcast as a solid fertilizer within the treatment plot; when applied with the irrigation treatment, it was applied either as a liquid in the irrigation stream or as a solid broadcast treatment. The broadcast fertilizer treatments were applied annually whereas the liquid fertilization was applied in smaller doses throughout the growing season. The AU site had FI treatments where solid fertilizer was broadcast annually and where it was added in the irrigation stream; the GA site did not have an F treatment; the BR site had F and FI treatments but did not report them separately because there was no fertilizer effect on growth at that site; and the $\mathrm{HI}$ site had treatments we considered I and $\mathrm{FI}$ even though there was no irrigation because average annual rainfall

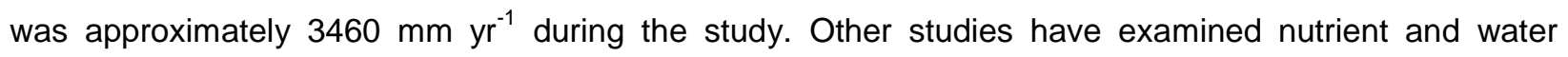
applications in forest stands (e.g. (Coyle et al., 2016)); however, the data necessary to complete LUE calculations were not published.

We examined LUE as biomass production per unit of intercepted light for stem, aboveground (stem, leaves and branches), and total (aboveground plus roots) biomass. Biomass production was the additional biomass produced in one year and the measurement of intercepted light was from the same 
year. Biomass production (growth over one year) is distinct from biomass accumulation (growth over the lifetime of the trees, many years), which is the total amount of biomass produced from the time of planting. When perennial tissue (stems, branches and roots) production data were not specifically provided but biomass accumulation (biomass pool size) data for consecutive years were found, we estimated production by calculating the difference between the pool sizes from year to year. When production data were reported as carbon, the data were converted to biomass by multiplying the carbon data by 2 (IPCC, 2006). Aboveground production data were available for all sites, stem production data were available for seven sites (BR, FR, GA, NC, PT, SE, ZA) and total production data were available for five sites (FR, GA, NC, SE, and ZA) (Table 2). Intercepted light was defined as photosynthetically active radiation (PAR) absorbed by the canopy. Some studies reported absorbed PAR; where absorbed PAR $\left(\mathrm{I}_{\mathrm{ABS}}\right)$ was not reported, we estimated it as

$$
\text { [1] } \mathrm{I}_{\mathrm{ABS}}=\mathrm{I}_{\mathrm{O}}\left[1-\exp ^{(-\mathrm{kL})}\right]
$$

where $\mathrm{I}_{\mathrm{O}}$ is above-canopy irradiance, $\mathrm{k}$ is the extinction coefficient, and $\mathrm{L}$ is leaf area index (Landsberg, 1986). When above-canopy irradiance was not found in the literature for a site, we acquired these data from publicly available data stores (Agri4cast (2015)), or we acquired temperature and rainfall data from other sources (CRONOS (2015) and NOAA NCDC (Menne et al., 2012)) and used SolarCalc (Spokas and Forcella, 2006) to estimate the above-canopy irradiance. When absorbed PAR was presented in moles of absorbed PAR, we converted to MJ by dividing by 4.6 (Boelee et al., 2012). Extinction coefficients and leaf area indices were obtained from the literature or were measured for this analysis (Table 2).

We estimated the additional carbon that would be stored in aboveground biomass in response to treatment by subtracting the aboveground biomass production of the control from that of the treatments at each site. The result was divided by 2 to calculate the carbon in the biomass (IPCC, 2006) and then multiplied by 3.667 to convert the biomass carbon into $\mathrm{CO}_{2}$ equivalents (USEPA, 2005). If multiple years of data were available for a given site, the $\mathrm{CO}_{2}$ equivalents were averaged across years. This calculation was only completed for sites (AU, FR, NC, PT, SE, ZA) that had all four (C, I, F, FI) treatments.

PROC MIXED (SAS-Institute, 2002) was used to examine our hypothesis regarding site and treatment effects on the relationships between intercepted light and aboveground, stem and total biomass 
production. We tested site, site by fertilization, site by irrigation and site by fertilization by irrigation as random effects on the relationship between intercepted light and aboveground, stem and total biomass production (Littell et al., 2006). Intercepted light was a fixed effect. Eight of the nine studies (all except GA) had production and absorbed PAR estimates from multiple years. Consequently, stand age was used as a repeated measure in the mixed model. As noted previously, not all treatments were installed at all sites, which resulted in missing data points for these sites and an unbalanced design. Heteroscedasticity was observed in the aboveground and stem biomass production data, and a log transformation was used to normalize these data. If terms in the full model were not significant, they were removed from the model until all model terms were significant. When all terms in the model were significant, parameter estimates were generated to produce a regression line to fit the data. The slopes of the production versus intercepted light regression lines were scaled from $\mathrm{Mg} \mathrm{ha}^{-1} \mathrm{yr}^{-1} \mathrm{per} \mathrm{MJ} \mathrm{m}^{-2} \mathrm{yr}^{-1}$, to $\mathrm{g} \mathrm{MJ}^{-1}$ by converting the units to a common area and scaling to grams. All statistical tests were evaluated 232 with alpha $=0.05$.

\section{Results} 1.21 , and $0.85 \mathrm{~g} \mathrm{MJ}^{-1}$, respectively (Figs. 1, 2, and 3, respectively).

$\mathrm{F}$, and $\mathrm{FI}$ treatments was 3.9, 6.8 and $13.4 \mathrm{Mg} \mathrm{CO}_{2}$ equivalents $\mathrm{ha}^{-1} \mathrm{yr}^{-1}$, respectively (Fig. 4).

\section{Discussion} annually as dry material to the soil surface and one where fertilizer was added in the irrigation stream throughout the growing season. Only the AU site included both treatments; however, the study design

244 did not permit a statistical analysis of treatment differences (Snowdon and Benson, 1992). The potential 245 differences arising from the fertilizer application method are that the dry material applications could be susceptible to urea volatilization such that less nitrogen would be available to the trees than what was applied (Cabrera et al., 2010), although the use of urease inhibitors can effectively eliminate this as an 
issue (Zerpa and Fox, 2011). Additionally, applying fertilizers in the irrigation stream may supply the nutrients at the time of demand and in a manner that makes uptake relatively efficient. In the studies where solid fertilizer was applied with irrigation, the annual applications were completed at the start of the growing season; however, the level of nitrogen in the soil was increased for several months (Mudano, 1986). At the same time, at the sites where fertilizer was added as a dry material, care was taken to apply the fertilizer in a manner to reduce or eliminate the possibility of volatilization and consequently, we believe there was no reason to consider these as different treatments.

For the individual sites, treatment did influence growth, with positive fertilizer responses observed at $\mathrm{AU}, \mathrm{FR}, \mathrm{HI}, \mathrm{NC}$, and $\mathrm{SE}$ and positive irrigation responses at $\mathrm{AU}, \mathrm{BR}, \mathrm{NC}, \mathrm{PT}$ and $\mathrm{ZA}$ (Raison and Myers, 1992; Pereira et al., 1994; Albaugh et al., 1998; Bergh et al., 1999; Ryan et al., 2004; Samuelson et al., 2004; Campion et al., 2006; Stape et al., 2008; Trichet et al., 2008). In addition, several sites, including $\mathrm{AU}$ and $\mathrm{GA}$, had strong positive responses to the combination of fertilizer and irrigation. The typical aboveground biomass response to either treatment (water or nutrients) was an increase in foliage and stem production. When examining total production, the typical response was an increase in foliage and stem production and a decrease in belowground production with improved nutrition (e.g. (Samuelson et al., 2004)). This effect was repeated in some cases, although to a lesser degree, with irrigation (Albaugh et al., 1998).

However, in our study, site and site by treatment interactions did not affect LUE calculated using aboveground, stem or total biomass production. Consequently, we rejected our hypothesis. This was surprising given the wide range in species and sites included in the analysis. Species from three genera (Eucalyptus, Pinus and Picea) and sites ranging from 12 to 64 degrees of latitude were examined (Table 1). The imposed treatments induced large gradients in nutrient and water availability at each site, and the responses observed differed by site, where some sites responded well to irrigation (Raison and Myers, 1992; Campion et al., 2006; Stape et al., 2008) while others responded primarily to fertilization (Albaugh et al., 1998; Bergh et al., 1999; Ryan et al., 2004). Across all studies, absorbed PAR ranged from 1000 to $3000 \mathrm{MJ} \mathrm{m}^{-2} \mathrm{yr}^{-1}$ and aboveground, stem and total biomass production ranged from 3 to 30,2 to 28 , and 5 to $32 \mathrm{Mg} \mathrm{ha}^{-1} \mathrm{hr}^{-1}$, respectively. Even with these large differences in site and imposed treatments, we did not detect differences in LUE due to site and site by treatment interactions. Multiple species-site 
combinations have exhibited similar LUE for crops (Monteith, 1977) and tree species (Linder, 1985;

277 Cannell, 1989a). In addition, Runyon et al. (1994) reported similar LUE values across species after

278 adjusting for climatic and environmental constraints. In our analysis, no adjustments were made for these constraints. Other studies have identified differences in aboveground LUE. For example, Dallatea and Jokela (1991) reported different aboveground LUE values for Pinus taeda and Pinus elliottii Engelm., which these authors attributed to variation in crown structure between the two species. In addition, Ahl et al. (2004) examined aboveground LUE for five forest cover types (aspen, northern hardwoods, red pine, forested wetlands and upland conifers) and found differences due to cover type and year.

The slope of the aboveground biomass production versus intercepted light regression line was $0.0151 \mathrm{Mg} \mathrm{ha}^{-1} \mathrm{yr}^{-1}$ per MJ m $\mathrm{mr}^{-1}$, which, after converting the units to a common area and scaling to grams, results in $1.51 \mathrm{~g} \mathrm{MJ}^{-1}$ of biomass production on an annual basis. This is similar to Monteith's (1977) estimate of $1.4 \mathrm{~g} \mathrm{MJ}^{-1}$ for annual dry matter production for crops, Linder's (1985) estimate of $1.7 \mathrm{~g}$ $\mathrm{MJ}^{-1}$ for aboveground production in Eucalyptus, Pinus and Picea stands in Australia, New Zealand, Sweden and the United Kingdom, and the range of aboveground production in plantation species around the world (0.2-2.4 $\left.\mathrm{g} \mathrm{MJ}^{-1}\right)$ listed by Landsberg and Sands (2011). The range in aboveground LUE for forests and forest plantations clusters around 1.0-1.5 $\mathrm{g} \mathrm{MJ}^{-1}$, which is in agreement with our estimate (Waring et al., 1998). Waring and Running (1998) suggested that Monteith's estimate would not be achieved in forests due to typical suboptimal conditions that limit stomatal opening and cause trees to allocate excess carbon belowground. Temperature differences, vapor pressure deficit and water stress have been identified as causing variation in LUE (McMurtrie et al., 1994). In addition, it has been hypothesized that the canopy nitrogen content may influence light use efficiency to maintain it at a constant level (Medlyn, 1998). Given that the nutrient and water treatments imposed in these studies would have a large effect on water stress (i.e. reduce it in irrigated treatments) and the canopy nitrogen content (increase it and reduce within-canopy variation), and that these effects would occur across site 300 and species may help explain the lack of a significant site effect. Using a biochemical approach, Amthor 301 (2010) estimated the theoretical maximum light use efficiency for $\mathrm{C}_{3}$ crop plants as $0.092 \mathrm{~J} \mathrm{~J}^{-1}$. Converting 302 our aboveground biomass LUE estimate to the same units using $20 \mathrm{MJ} \mathrm{kg}^{-1}$ as the approximate 303 phytomass heat of combustion (Gower et al., 1984), our LUE estimate is $0.03 \mathrm{~J} \mathrm{~J}^{-1}$, approximately one- 
third of the theoretical maximum. Reduction from the maximum LUE would be a result of non-optimal temperature and nutrient and water limitations (Landsberg, 1986).

Stem biomass LUE was similar in both slope and intercept to the aboveground biomass LUE

(Figs 1 and 2). This is not surprising because stem production represents a large proportion of aboveground and total production. In the studies examined here, stem production was, on average, approximately $65 \%$ and $51 \%$ of aboveground and total production, respectively. Stem production was relatively sensitive to nutrient and water availability in the studies examined here, where changes in resource availability resulted in large effects on stem production, often due to a change in carbon allocation from belowground to aboveground components (Ryan et al., 2004).

Similarly, the slope of the total production versus intercepted light was $0.00854 \mathrm{Mg} \mathrm{ha}^{-1} \mathrm{yr}^{-1}$ per $314 \mathrm{MJ} \mathrm{m}^{-2} \mathrm{yr}^{-1}$, which results in $0.85 \mathrm{~g} \mathrm{MJ}^{-1}$ of biomass production. These results are in the range of 315 estimates from the literature for total production (1.4-1.6 $\mathrm{g} \mathrm{MJ}^{-1}$ (du Toit, 2008), 1.25 (Runyon et al., 316 1994), 0.30-0.45 (Ahl et al., 2004) and 0.3-3.3 $\mathrm{g} \mathrm{MJ}^{-1}$ (Landsberg and Sands, 2011)). The intercept for 317 the aboveground biomass production versus intercepted light relationship was -11.2 and significantly less 318 than zero. Linder's (1985) intercept estimate for the same relationship was also less than zero, and he 319 indicated this was to be expected because only aboveground production was included. Consequently, we concluded that by including belowground biomass production, the intercept should be zero. The intercept for our total biomass versus intercepted light relationship was not significantly different from zero (Fig. 3), 322 as predicted by Linder (1985). Given the difficulty in quantifying belowground production (Stone and 323 Kalisz, 1991), this result gives confidence that the root production estimates from these studies well estimated belowground production. It is counterintuitive that the total biomass production slope $(0.85 \mathrm{~g}$ $\left.\mathrm{MJ}^{-1}\right)$ was less than both the stem $\left(1.21 \mathrm{~g} \mathrm{MJ}^{-1}\right)$ and aboveground $\left(1.51 \mathrm{~g} \mathrm{MJ}^{-1}\right)$ slopes. This is a result of 326 using a different population for each estimate, where all nine sites were used for aboveground biomass, whereas only seven and five sites, respectively, were used for the stem and total production estimates.

328 Additionally, the total production regression equation has an intercept of zero while the aboveground and 329 stem relationships have negative intercepts. Intercepted light was the independent variable in this analysis. It is important to note that even though light is being intercepted, additional carbon may not be fixed and growth may not continue. In 
extreme northern climates, for example, the photosynthetic machinery is damaged by extended cold periods and in spring, light may be intercepted by the foliage, but photosynthesis remains well below what would be expected (Bergh et al., 1998). However, improved nutrition can reduce this effect, allowing the photosynthetic machinery to recover more rapidly when conditions improve in spring (Bergh et al., 2003). Similarly, when water limitations occur, stomates close to conserve water so that photosynthesis is reduced or stopped even though the foliage continues to intercept light (Campion et al., 2006; Stape et al., 2008). On the other end of the spectrum, growth may be limited even though the photosynthetic machinery is operating at a maximum for a particular species. While growth may continue through the utilization of stored carbohydrates, once these are depleted, the additional growth that would be expected based on the total amount of intercepted light does not occur (Sampson et al., 2001). Additionally, increasing stand age during the experiments would have influenced the observed LUE, where older stands would likely have less aboveground biomass production for a given level of intercepted light than a younger stand (Ryan et al., 2004). Sites in this study had quite varied environmental constraints that may have resulted in a situation where light was intercepted but additional carbon was not fixed. Low temperature certainly influenced growth at SE and would have also had an effect at NC, GA and FR, whereas high vapor pressure deficit likely influenced growth at AU, ZA and BR. Linder (1985) reported a common LUE for sites from Australia, New Zealand, the United Kingdom and Sweden and after adjusting for environmental constraints, Runyon et al. (1994) reported a common LUE along a transect in Oregon, which included a wide range of vegetation zones. Medlyn (1998) suggested that there may be a compensatory mechanism among PAR, leaf area index and leaf nitrogen content that resulted in similar LUE values across the different sites in the Runyon et al. (1994) study. Nutrient applications in the studies examined here would have increased the foliar nitrogen content, and the nutrient and water treatments affected leaf area index. It is possible that part of the explanation for our common LUE values is related to these factors as well.

The amount of carbon that might be stored as biomass if these treatments were applied on a broader scale would be influenced by the amount of fertilizer applied and the response achieved. The studies examined here were designed as nutrient optimization studies to ameliorate all nutrient deficiencies. The trees were monitored on a regular basis to ensure they received not only nitrogen and 
phosphorus, but all elements that were or might become limiting. While this level of monitoring may be problematic at an operational scale, responses similar to those observed in the optimum nutrition studies have been obtained from less frequent applications of nitrogen and phosphorus applied to Pinus taeda in the southeastern United States (Fox et al., 2007). Similar results were reported from a series of experiments with Picea abies in Sweden, where biannual application of fertilizers did not reduce the growth response nor increase nitrogen leaching to soil water compared to annual applications (Bergh et al., 2008). A typical mid-rotation fertilizer application in a Pinus taeda stand sequestered $19.2 \mathrm{Mg} \mathrm{CO} 2$ equivalents $\mathrm{ha}^{-1}$ as additional stem growth per unit of $\mathrm{CO}_{2}$ equivalent emissions associated with the fertilizer application (Albaugh et al., 2012).

Additional carbon is likely stored in increased branch, root mass, and soil organic matter associated with the response to fertilization. Generally, less carbon is proportionally allocated 371 belowground as root mass in response to additional nutrients (e.g. (Albaugh et al., 1998; Campion et al., 372 2006); however, fertilized trees are typically larger than non-fertilized trees, and the absolute root mass will be higher. This additional carbon storage is only focused on what occurs in the forest, whereas other benefits exist after stands have been harvested. In one modelling analysis, after five successive rotations where fertilizers were applied once in mid-rotation stands, $38 \%$ of the $\mathrm{CO}_{2}$ equivalents resulting from fertilization remained in use or in a landfill compared with $36 \%$ that was used as an energy source 377 (Albaugh et al., 2012).

In the southeastern United States, up to 600,000 ha have been fertilized annually, resulting in increased annual carbon sequestration of more than $8 \mathrm{Tg} \mathrm{yr}^{-1} \mathrm{CO}_{2}$ equivalents on an area basis. Other 380 parts of the world have fertilized large amounts of forest areas, for example, 190,000 ha $\mathrm{yr}^{-1}$ were fertilized in Sweden in the 1970's (Nohrstedt, 2001) and as much as 110,000 ha $\mathrm{yr}^{-1}$ were fertilized in Finland up to the 1990's (Saarsalmi and Malkonen, 2001). These amounts have dropped considerably due to concern over negative environmental impacts associated with nutrient movement offsite, including 384 eutrophication of water systems (e.g. (Bennett et al., 2001; Driscoll et al., 2003). However, the nutrient 385 optimization studies have demonstrated that nutrients can be added to the forest without nutrient movement offsite (Linder, 1995). Irrigating forest stands may not be logistically practical on a large scale;

387 however, our data indicate a substantial increase in stored carbon that could be gained with irrigation 
alone on some sites. One possibility for irrigating forest stands, which may alleviate wastewater disposal problems, is to use wastewater treated to remove heavy metals, toxins, microbes and other components that might be problematic as the source for the irrigation water, similar to the AU experiment (Raison and Myers, 1992) and other studies (Cromer et al., 1983). Regardless of the water source, irrigation might become an important consideration in areas such as Brazil, Australia and South Africa, where water may be severely limiting at times. In Brazil, there was no response from fertilization, but there was a large response to irrigation (Stape et al., 2008), while in Australia, fertilization alone provided a modest response but there was a synergistic response when fertilization and irrigation were combined (Raison and Myers, 1992). In South Africa, Eucalyptus species require nutrient additions to develop high levels of leaf area needed for high productivity but then require water additions to sustain that leaf area (Campion, 2005). These benefits need to be considered in light of potential water limitations for other needs in the future (King et al., 2013). In addition to the potential for mitigating climate change by increasing carbon stored in forest stands, bioenergy from forest products has interesting potential. It already provides one third of Sweden's energy, and in the southeastern United States, demand for bioenergy exceeds 90

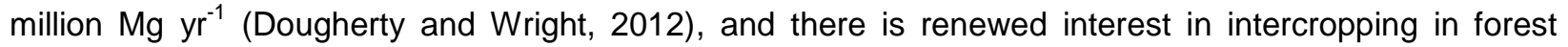
stands for the simultaneous production of bioenergy crops (King et al., 2013; Albaugh et al., 2014).

In this analysis, we did not detect site or treatment effects on the biomass production versus intercepted light relationship. Consequently, effects on biomass production per unit intercepted light were represented with one relationship at a scale covering a wide range in species, environments and resource availability. Treatment effects on growth efficiency (described as stem growth per unit leaf area) were evident in the studies included in this analysis (e.g. (Raison and Myers, 1992; Trichet et al., 2008)) and have been reported in other studies (Waring et al., 1981; Linder, 1987; Will et al., 2002). Examining intercepted light, rather than leaf area index directly, likely incorporated the treatment effect in the independent variable, thus eliminating treatment as a significant regressor. Additionally, the nutrient applications may have increased foliar nitrogen content, and the nutrient and water treatments may have increased leaf area index such that there was a compensatory mechanism among PAR, leaf area index and leaf nitrogen that resulted in similar LUE values across site (Medlyn, 1998). The information 
415 presented here will be useful for predicting responses to silvicultural treatment and in modeling efforts 416 involved in quantifying global productivity from remotely sensed data. 


\section{Figure legends}

Fig. 1. Aboveground biomass production versus absorbed photosynthetically active radiation (PAR) for nine sites (AU - Pinus radiata in Australia; BR - Eucalyptus grandis x urophylla in Brazil; FR - P. pinaster in France; GA - P. taeda in Georgia, United States; HI - E. saligna in Hawaii, United States; NC - P. taeda in North Carolina, United States; PT - E. globulus in Portugal; SE - Picea abies in Sweden; and ZA - E. grandis in South Africa) where nutrient optimization and irrigation studies were installed with four treatments ( $\mathrm{C}$ - control with no additions (red symbols), I optimum irrigation (gray symbols), F - optimum fertilization (green symbols), FI - optimum fertilization and irrigation (blue symbols)). Multiple points for a site-treatment combination indicate different years where the measurements were completed. The regression line (REG) is for all data; there were no significant site, treatment or interactive effects on the relationship. The regression equation is shown.

Fig. 2. Stem biomass production versus absorbed photosynthetically active radiation (PAR) for seven sites (BR - Eucalyptus grandis x urophylla in Brazil; FR - P. pinaster in France; GA - P. taeda in Georgia, United States; NC - P. taeda in North Carolina, United States; PT - E. globulus in Portugal; SE - Picea abies in Sweden; and ZA - E. grandis in South Africa) where nutrient optimization and irrigation studies were installed with four treatments $(C-$ control with no additions (red symbols), I - optimum irrigation (gray symbols), F - optimum fertilization (green symbols), FI - optimum fertilization and irrigation (blue symbols)). Multiple points for a sitetreatment combination indicate different years where the measurements were completed. The regression line (REG) is for all data; there were no significant site, treatment or interactive effects on the relationship. The regression equation is shown.

Fig. 3. Total biomass production versus absorbed photosynthetically active radiation (PAR) for five sites (FR - P. pinaster in France; GA - P. taeda in Georgia; United States, NC - P. taeda in North Carolina, United States; SE - Picea abies in Sweden; and ZA - E. grandis in South Africa) where nutrient optimization and irrigation studies were installed with four treatments $(C-$ control with no additions (red symbols), I - optimum irrigation (gray symbols), F - optimum fertilization (green symbols), FI - optimum fertilization and irrigation (blue symbols)). Multiple points for a site- 
treatment combination indicate different years where the measurements were completed. The regression line $(R E G)$ is for all data; there were no significant site, treatment or interactive effects on the relationship. The regression equation is shown; the intercept was not significantly different from zero and therefore a no-intercept model was used.

449 Fig. 4. Additional aboveground carbon stored in response to treatment for six sites (AU - Pinus radiata in Australia; FR - P. pinaster in France; NC - P. taeda in North Carolina, United States; PT - E. globulus in Portugal; SE - Picea abies in Sweden; and ZA - E. grandis in South Africa) where nutrient optimization and irrigation studies were installed with four treatments $(C-$ control with no additions, I - optimum irrigation, F - optimum fertilization, $\mathrm{FI}$ - optimum fertilization and irrigation). Data are the treated minus control values showing the average response over all years where measurements were completed. Negative values indicate that the control grew better than the treated plots at that site. 


\section{Acknowledgements}

458 We appreciate support from Forest Productivity Cooperative members, staff and students for their role in 459 the establishment and management of the Southeast Tree Research and Education Site trial. We 460 gratefully acknowledge the support provided by the Department of Forest Resources and Environmental 461 Conservation at Virginia Polytechnic Institute and State University, the Departamento de Silvicultura, 462 Facultad de Ciencias Forestales, Universidad de Concepción, and the Department of Forestry and 463 Environmental Resources at North Carolina State University. Funding for this work was provided in part 464 by the Virginia Agricultural Experiment Station and the Mclntire-Stennis Program of the National Institute 465 of Food and Agriculture, U.S. Department of Agriculture. Additional support was provided by The Pine 466 Integrated Network: Education, Mitigation, and Adaptation Project (PINEMAP), a Coordinated Agricultural

467 Project funded by the USDA National Institute of Food and Agriculture, Award \#2011-68002-30185. The 468 use of trade names in this paper does not imply endorsement by the associated agencies of the products 469 named, nor criticism of similar ones not mentioned. 
Table 1. Location, species, age, years measured and citation details of each experiment examined in this analysis. Negative latitude and longitude indicate south and west, respectively.

\begin{tabular}{|c|c|c|c|c|c|c|c|}
\hline Site & $\begin{array}{l}\text { Site } \\
\text { code }\end{array}$ & Latitude & Longitude & Species & $\begin{array}{c}\text { Age } \\
\text { (years) }\end{array}$ & $\begin{array}{c}\text { Years } \\
\text { examined }\end{array}$ & Primary citation \\
\hline Australia & $\mathrm{AU}$ & -35.34 & 148.94 & Pinus radiata & $10-14$ & $1983-1987$ & Raison and Myers 1992 \\
\hline Brazil & BR & -11.97 & -38.12 & Eucalyptus grandis $x$ urophylla & $4-5$ & 2000 & Stape et al., 2008 \\
\hline France & FR & 44.70 & -0.77 & Pinus pinaster & $7-9$ & $1999-2001$ & Trichet et al., 2008 \\
\hline Georgia & GA & 30.80 & -84.65 & Pinus taeda & 4 & 1998 & Samuelson et al., 2004 \\
\hline Hawaii & $\mathrm{HI}$ & 19.84 & -155.12 & Eucalyptus saligna & $1-6$ & $1995-2000$ & Ryan et al., 2004 \\
\hline North Carolina & NC & 35.90 & -79.48 & Pinus taeda & 8-16 & $1992-2000$ & Albaugh et al., 1998 \\
\hline Portugal & PT & 39.03 & -9.25 & Eucalyptus globulus & $1-3$ & 1987-1989 & Pereira et al., 1994 \\
\hline South Africa & ZA & -27.23 & 30.55 & Eucalyptus grandis & $2-4$ & $2000-2002$ & Campion et al., 2006 \\
\hline Sweden & $\mathrm{FL}$ & 64.12 & 19.45 & Picea abies & $32-33$ & $1995-1996$ & Bergh et al., 1999 \\
\hline
\end{tabular}


Table 2. Data sources for estimating aboveground and total biomass production, and intercepted light or the components needed to estimate intercepted light (above-canopy irradiance, the extinction coefficient and leaf area index) for the nine sites examined. NR indicates that the variable was not reported.

\begin{tabular}{|c|c|c|c|c|c|c|}
\hline Site & $\begin{array}{l}\text { Aboveground } \\
\text { production }\end{array}$ & $\begin{array}{l}\text { Total } \\
\text { production }\end{array}$ & $\begin{array}{l}\text { Intercep } \\
\text { ted light } \\
\left(\mathrm{l}_{\mathrm{abs}}\right)\end{array}$ & $\begin{array}{l}\text { Above-canopy } \\
\text { irradiance (lo) }\end{array}$ & $\begin{array}{l}\text { Extinction } \\
\text { coefficient }(\mathrm{k})\end{array}$ & $\begin{array}{l}\text { Leaf area } \\
\text { index }\end{array}$ \\
\hline Australia & $\begin{array}{l}\text { Raison and } \\
\text { Myers, 1992) }\end{array}$ & NR & $\begin{array}{l}\text { (Raison } \\
\text { and } \\
\text { Myers, } \\
\text { 1992) }\end{array}$ & -- & -- & -- \\
\hline Brazil & $\begin{array}{l}\text { (Stape et al., } \\
\text { 2008) }\end{array}$ & NR & $\begin{array}{l}\text { (Stape } \\
\text { et al., } \\
2008)\end{array}$ & -- & -- & -- \\
\hline France & $\begin{array}{l}\text { (Trichet et al., } \\
\text { 2008) }\end{array}$ & $\begin{array}{l}\text { (Trichet et al., } \\
\text { 2008) }\end{array}$ & --' & Agri4cast (2015) & $\begin{array}{l}\text { 0.47, (Berbigier and } \\
\text { Bonnefond, 1995) }\end{array}$ & $\begin{array}{l}\text { (Trichet et } \\
\text { al., 2008) }\end{array}$ \\
\hline Georgia & $\begin{array}{l}\text { (Samuelson et } \\
\text { al., 2001) }\end{array}$ & $\begin{array}{l}\text { (Samuelson et } \\
\text { al., 2001) }\end{array}$ & -- & $\begin{array}{l}\text { CRONOS (2015), } \\
\text { SolarCalc (Spokas } \\
\text { and Forcella, } \\
\text { 2006) }\end{array}$ & $\begin{array}{l}\text { 0.5, (Sampson and } \\
\text { Allen, 1995) }\end{array}$ & $\begin{array}{l}\text { (Samuels } \\
\text { on et al., } \\
2004)\end{array}$ \\
\hline Hawaii & $\begin{array}{l}\text { (Ryan et al., } \\
\text { 2004) }\end{array}$ & NR & & $\begin{array}{l}\text { NOAA National } \\
\text { Climatic Data } \\
\text { Center, SolarCalc. } \\
\text { (Spokas and } \\
\text { Forcella, 2006; } \\
\text { Menne et al., } \\
\text { 2012) }\end{array}$ & $\begin{array}{l}\text { 0.36, (Stape et al., } \\
\text { 2004) }\end{array}$ & \\
\hline $\begin{array}{l}\text { North } \\
\text { Carolina }\end{array}$ & $\begin{array}{l}\text { (Albaugh et } \\
\text { al., 1998; } \\
\text { Albaugh et al., } \\
\text { 2004) }\end{array}$ & $\begin{array}{l}\text { (Albaugh et } \\
\text { al., 1998; } \\
\text { Albaugh et al., } \\
\text { 2004) }\end{array}$ & -- & $\begin{array}{l}\text { On site weather } \\
\text { station }\end{array}$ & $\begin{array}{l}\text { 0.5, (Sampson and } \\
\text { Allen, 1995) }\end{array}$ & $\begin{array}{l}\text { (Albaugh } \\
\text { et al., } \\
\text { 1998; } \\
\text { Albaugh } \\
\text { et al., } \\
2004 \text { ) }\end{array}$ \\
\hline Portugal & $\begin{array}{l}\text { (Madeira and } \\
\text { Pereira, 1990; } \\
\text { Pereira et al., } \\
\text { 1994) }\end{array}$ & NR & -- & Agri4cast (2015) & $\begin{array}{l}\text { 0.48, (Gazarini et } \\
\text { al., 1991) }\end{array}$ & $\begin{array}{l}\text { (Pereira et } \\
\text { al., 1994) }\end{array}$ \\
\hline $\begin{array}{l}\text { South } \\
\text { Africa }\end{array}$ & $\begin{array}{l}\text { (Campion et } \\
\text { al., 2006) }\end{array}$ & $\begin{array}{l}\text { (Campion et } \\
\text { al., 2006) }\end{array}$ & -- & (Campion, 2005) & $\begin{array}{l}\text { Treatment specific } \\
0.42-0.55 \text { (du Toit, } \\
\text { 2008) }\end{array}$ & $\begin{array}{l}\text { (Campion } \\
\text { et al., } \\
2005)\end{array}$ \\
\hline Sweden & $\begin{array}{l}\text { (Albaugh et } \\
\text { al., 2009b) }\end{array}$ & Unpublished & -- & $\begin{array}{l}\text { On site weather } \\
\text { station }\end{array}$ & $\begin{array}{l}\text { Treatment specific } \\
0.45-0.60\end{array}$ & $\begin{array}{l}\text { Unpublish } \\
\text { ed }\end{array}$ \\
\hline
\end{tabular}




\section{References}

Agri4Cast. 2015. European Commission Agri4Cast Resources Portal. European Commission http://agri4cast.jrc.ec.europa.eu/DataPortal/. Date accessed: January 11, 2016

Ahl, D.E., Gower, S.T., Mackay, D.S., Burrows, S.N., Norman, J.M., Diak, G.R., 2004. Heterogeneity of light use efficiency in a northern Wisconsin forest: implications for modeling net primary production with remote sensing. Remote Sensing of Environment 93, 168-178.

Albaugh, J.M., Albaugh, T.J., Heiderman, R.R., Leggett, Z., Stape, J.L., King, K., O'Neill, K.P., King, J.S., 2014. Evaluating changes in switchgrass physiology, biomass, and light-use efficiency under artificial shade to estimate yields if intercropped with Pinus taeda L. Agroforestry Systems 88, 489-503.

Albaugh, J.M., Dye, P.J., King, J.S., 2013. Eucalyptus and water use in South Africa. International Journal of Forestry Research 2013, 1-11.

Albaugh, T.J., Allen, H.L., Dougherty, P.M., Johnsen, K.H., 2004. Long term growth responses of loblolly pine to optimal nutrient and water resource availability. For.Ecol.Manage. 192, 3-19.

Albaugh, T.J., Allen, H.L., Dougherty, P.M., Kress, L.W., King, J.S., 1998. Leaf area and above- and belowground growth responses of loblolly pine to nutrient and water additions. For.Sci. 44, 317-328.

Albaugh, T.J., Allen, H.L., Fox, T.R., Carlson, C.A., Rubilar, R.A., 2009a. Opportunities for fertilization of loblolly pine in the Sandhills of the southeastern United States. South.J.Appl.For. 33, 129-136.

Albaugh, T.J., Bergh, J., Lundmark, T., Nilsson, U., Stape, J.L., Allen, H.L., Linder, S., 2009b. Do biological expansion factors adequately estimate stand-scale aboveground component biomass for Norway spruce. For.Ecol.Manage. 258, 2628-2637.

Albaugh, T.J., Vance, E.D., Gaudreault, C., Fox, T.R., Allen, H.L., Stape, J.L., Rubilar, R.A., 2012. Carbon emissions and sequestration from fertilization of pine in the southeastern United States. For.Sci. $58,419-429$.

Amthor, J.S., 2010. Tansley Review: From sunlight to phytomass: on the potential efficiency of converting solar radiation to phyto-energy. New Phytol. 188, 939-959.

Bennett, E.M., Carpenter, S.R., Caraco, N.F., 2001. Human impact on erodable phosphorus and eutrophication: A global perspective. Bioscience 51, 227-234.

Berbigier, P., Bonnefond, J.M., 1995. Measurement and modelling of radiation transmission within a stand of maritime pine (Pinus pinaster Ait.). Ann.For.Sci. 52, 23-42.

Bergh, J., Freeman, M., Sigurdsson, B., Kellomaki, S., Laitinen, K., Niinisto, S., Peltola, H., Linder, S., 2003. Modelling the short-term effects of climate change on the productivity of selected tree species in Nordic countries. For.Ecol.Manage. 183, 327-340.

Bergh, J., Linder, S., Bergstrom, J., 2005. Potential production of Norway spruce in Sweden. For.Ecol.Manage. 204, 1-10. 
Bergh, J., Linder, S., Grip, H., Hedwall, P.O., Lundmark, T., 2008. Effects of frequency of fertilisations on production, foliar chemistry and nutrient leaching in young Norway spruce stands in Sweden. Silva Fennica 42, 721-733.

Bergh, J., Linder, S., Lundmark, T., Elfving, B., 1999. The effect of water and nutrient availability on the productivity of Norway spruce in northern and southern Sweden. For.Ecol.Manage. 119, 51-62.

Bergh, J., McMurtrie, R.E., Linder, S., 1998. Climatic factors controlling the productivity of Norway spruce: a model-based analysis. For.Ecol.Manage. 110, 127-139.

Boelee, N.C., Temmink, H., Janssen, M., Buisman, C.J.N., Wijfels, R.H., 2012. Scenario analysis of nutrient removal from municipal wastewater by microalgal biofilms. Water 4, 460-473.

Byrne, S.V., Wentworth, T.R., Nusser, S.M., 1987. A moisture strain index for loblolly pine. Can.J.For.Res. 17, 23-26.

Cabrera, M.L., Kissel, D.E., Craig, J.R., Qafoku, N.P., Vaio, N., Rema, J.A., Morris, L.A., 2010. Relative humidity controls ammonia loss from urea applied to loblolly pine. Soil Sci.Soc.Am.J. 74, 543-549.

Campion, J.M., 2005. Climatic and nutritional controls on growth of Eucalyptus grandis in South Africa. In, Department of Animal, Plant and Environmental Sciences, Faculty of Science. University of the Witwatersrand, Johannesburg, p. 148.

Campion, J.M., Esprey, L.J., Scholes, M.C., 2005. Application of the 3-PG model to a Eucalyptus grandis stand subject to varying levels of water and nutritional constraints in KwaZulu-Natal, South Africa. Southern African Forestry Journal 203, 3-13.

Campion, J.M., Nkosana, M., Scholes, M.C., 2006. Biomass and N and P pools in above- and belowground components of an irrigated and fertilised Eucalyptus grandis stand in South Africa. Aust.For. 69, 48-57.

Cannell, M.G.R., 1989a. Light interception, light use efficiency and assimilate partitioning in poplar and willow stands. In: Pereira, J.S., Landsberg, J.J. (Eds.), Biomass production by fast-growing trees. Kluwer Academic Publishers, The Netherlands, pp. 1-12.

Cannell, M.G.R., 1989b. Physiological basis of wood production: a review. Scand.J.For.Res. 4, 459-490.

Coyle, D.R., Aubrey, D.P., Coleman, M.D., 2016. Growth repsonses of narrow or broad site adapted tree species to a range of resource availability treatments after a full harvest rotation. For.Ecol.Manage. 362 , 107-119.

Cromer, R.N., Tompkins, D., Barr, N.J., 1983. Irrigation of Pinus radiata with wastewater: tree growth in response to treatment. Aust.For.Res. 13, 57-65.

CRONOS. 2015. State Climate Office of North Carolina CRONOS [Internet database on climate in the southeast US]. NC State University. http://climate.ncsu.edu/cronos/. Date accessed: January 7, 2016

Dallatea, F., Jokela, E.J., 1991. Needlefall, Canopy Light Interception, and Productivity of Young Intensively Managed Slash and Loblolly-Pine Stands. For.Sci. 37, 1298-1313.

Dougherty, D., Wright, J., 2012. Silviculture and economic evaluation of eucalypt plantations in the southern US. Bioresources 7, 1994-2001. 
Driscoll, C.T., Whitall, D., Aber, J.D., Boyer, E., Castro, M., Cronan, C., Goodale, C.L., Groffman, P., Hopkinson, C., Lambert, K., Lawrence, G., Ollinger, S.V., 2003. Nitrogen pollution in the northeastern United States: Source, effects and management options. Bioscience 2003, 4.

du Toit, B., 2008. Effects of site management on growth, biomass partitioning and light use efficiency in a young stand of Eucalyptus grandis in South Africa. For.Ecol.Manage. 255, 2324-2336.

Ewers, B.E., Oren, R., Sperry, J.S., 2000. Influence of nutrient versus water supply on hydraulic architecture and water balance in Pinus taeda. Plant, Cell and Environment 23, 1055-1066.

Fox, T.R., Allen, H.L., Albaugh, T.J., Rubilar, R.A., Carlson, C.A., 2007. Tree nutrition and forest fertilization of pine plantations in the southern United States. South.J.Appl.For. 31, 5-11.

Gazarini, L.C., Araújo, M.C., Borralho, N., Pereira, J.S., 1991. Plant area index in Eucalyptus globulus plantations determined indirectly by a light interception method. Tree Physiol. 7, 107-113.

Gower, S.T., Frederick, D.J., Clark, A., .III, 1984. Distribution of energy in different-aged southeastern bottomland forests. For.Ecol.Manage. 9, 127-146.

Hanna, S.A., Glover, G.R., Lockaby, B.G., Zutter, B.R., Torbert, J., 1999. Soil nitrogen response to vegetation control and fertilization in a midrotation loblolly pine stand. In, So.Weed Sci.Soc.Annual Meeting, pp. 112-113.

Ingestad, T., 1974. Towards optimum nutrition. Ambio 3, 49-54.

Ingestad, T., 1977. Nitrogen and plant growth; maximum efficiency of nitrogen fertilizers. Ambio 6, 146151.

Ingestad, T., 1987. New concepts on soil fertility and plant nutrition as illustrated by research on forest trees. Geoderma 40, 237-252.

IPCC. 2006. Guidelines for national greenhouse gas inventories Volume 4 Agriculture, forestry, and other land use. http://www.ipcc-nggip.iges.or.jp/public/2006gl/vol4.html. Date accessed: March 14, 2016

Johnsen, K.H., Wear, D.N., Oren, R., Teskey, R.O., Sanchez, F.G., Will, R.E., Butnor, J., Markewitz, D., Richter, D.D., Rials, T., Allen, H.L., Ellsworth, D.S., Maier, C.A., Katul, G., Dougherty, P.M., 2001. Meeting global policy commitments: Carbon sequestration and southern pine forests. J.For. April, 4-21.

King, J.S., Ceulemans, R., Albaugh, J.M., Dillen, S.Y., Domec, J.C., Fichot, R., Fischer, M., Leggett, Z., Sucre, E., Trnka, M., Zenone, T., 2013. The challenge of lignocellulosic bioenergy in a water-limited world. Bioscience 63, 102-117.

Knecht, M.F., Göransson, A., 2004. Terrestrial plants require nutrients in similar proportions. Tree Physiol. $24,447-460$.

Landsberg, J.J., 1986. Physiological ecology of forest production. Academic Press, London. 1-198 p.

Landsberg, J.J., Sands, P.J., 2011. Physiological ecology of forest production Principles, processes and models. Academic Press, London. 1-331 p.

Linder, S., 1985. Potential and actual production in Australian forest stands. In: Landsberg, J.J., Parsons, W. (Eds.), Research for forest management. CSIRO, Melbourne, pp. 11-35. 
Linder, S., 1987. Response to water and nutrients in coniferous ecosystems. In: Schulze, E.D., Zwolfer, H. (Eds.), Potentials and limitations of ecosystem analysis. Springer-Verlag., Berlin, pp. 180-202.

Linder, S., 1995. Foliar analysis for detecting and correcting nutrient imbalances in Norway spruce. Ecological Bulletins 44, 178-190.

Linder, S., Waring, R.H., Landsberg, J.J., In review. Tamm Review: Insights gained from light use and leaf growth efficiency indices. For.Ecol.Manage.

Littell, R.C., Milliken, G.A., Stroup, W.W., Wolfinger, R.D., Schabenberger, O., 2006. SAS for mixed models. SAS Publishing, Cary, NC. 814 p.

Madeira, M., Pereira, J.S., 1990. Productivity, nutrient immobiulization and soil chemical properties in an Eucalyptus globulus plantation under different irrigation and fertilization regimes. Water Air and Soil Pollution 54, 621-634.

McMurtrie, R.E., Gholz, H.L., Linder, S., Gower, S.T., 1994. Climatic factors controlling the productivity of pine stands: a model-based analysis. Ecol. Bull. (Copenhagen) 43, 173-188.

Medlyn, B.E., 1998. Physiological basis of the light use efficiency model. Tree Physiol. 18, 167-176.

Menne, M.J., Durre, I., Vose, R.S., Gleason, B.E., Houston, T.G., 2012. An overview of the Global Historical Climatology Network-Daily Database. J. Atmospheric and Oceanic Technology 29, 897-910.

Monteith, J.L., 1977. Climate and the efficiency of crop production in Britain. Phil. Trans. R. Soc. Lond. B. 281, 277-294.

Mudano, J.E., 1986. Assessment of soil nitrogen availability following nitrogen and phosphorus fertilization of a loblolly pine stand. In. Dept. of Forestry, North Carolina State University, Raleigh, NC, pp. $1-52$.

Nohrstedt, H.O., 2001. Response of coniferous forest ecosystems on mineral soils to nutrient additions: A review of Swedish experiences. Scand.J.For.Res. 16, 555-573.

Pereira, J.S., Madeira, M., Linder, S., Ericsson, T., Tome, M., Araújo, M.C., 1994. Biomass production with optimised nutrition in Eucalyptus globulus plantations. In: Pereira, J.S., Pereira, H. (Eds.), Eucalyptus for Biomass Production. Commission of the European Communities, Lisbon, pp. 13-30.

Persson, T., 1980. Structure and function of northern coniferous forests - an ecosystem study. 32. Ecol. Bull., Stockholm. 609 p.

Raison, R.J., Myers, B.J., 1992. The Biology of Forest Growth experiment - Linking water and nitrogen availability to the growth of Pinus radiata. For.Ecol.Manage. 52, 279-308.

Running, S.W., Nemani, R., Heinsch, F.A., Zhao, M., Reeves, M., Hashimoto, H., 2004. A continuous satellite-driven measure of global terrestrial primary production. Bioscience 54, 547-560.

Running, S.W., Thornton, P.E., Nemani, R., Glassy, J.M., 2000. Global terrestrial gross and net primary productivity from the Earth Observing System. In: Sala, O.E., Jackson, R.B., Mooney, H.A., Howath, R.W. (Eds.), Methods in ecosystem sicence. Springer-Verlag, New York, pp. 44-57.

Runyon, J., Waring, R.H., Goward, S.N., Welles, J.M., 1994. Environmental limits on net primary production and light-use efficiency across the Oregon transect. Ecol. Appl. 4, 226-237. 
Ryan, M.G., 2013. Three decades of research at Flakaliden advancing whole-tree physiology, forest ecosystem and global change research. Tree Physiol. 33, 1123-1131.

Ryan, M.G., Binkley, D., Fownes, J.H., 1997. Age-related decline in forest productivity: Pattern and process. Advances in Ecological Research 27, 213-262.

Ryan, M.G., Binkley, D., Fownes, J.H., Giardina, C.P., Senock, R.S., 2004. An experimental test of the causes of forest growth decline with stand age. Ecol.Monogr. 74, 393-414.

Saarsalmi, A., Malkonen, E., 2001. Forest fertilization research in Finland: A literature review. Scand.J.For.Res. 16, 514-535.

Sampson, D.A., Allen, H.L., 1995. Direct and indirect estimates of leaf area index (LAl) for lodgepole and loblolly pine stands. Trees: Structure and Function 9, 119-122.

Sampson, D.A., Johnsen, K.H., Ludovici, K.H., Albaugh, T.J., Maier, C.A., 2001. Stand-scale correspondence in empirical and simulated labile carbohydrates in loblolly pine. For.Sci. 47, 60-68.

Samuelson, L.J., Johnsen, K.H., Stokes, T., 2004. Production, allocation, and stemwood growth efficiency of Pinus taeda L. stands in response to 6 years of intensive management. For.Ecol.Manage. 192, 59-70.

Samuelson, L.J., Stokes, T., Cooksey, T., McLemore, I., P., 2001. Production efficiency of loblolly pine and sweetgum in response to four years of intensive management. Tree Physiol. 21, 369-376.

SAS-Institute, 2002. SAS Version 9.1 TS. SAS Institute, Inc, Cary, NC. p.

Snowdon, P., Benson, M.L., 1992. Effects of combinations of irrigation and fertilisation on the growth and above-ground biomass production of Pinus radiata. For.Ecol.Manage. 52, 87-116.

Spokas, K., Forcella, F., 2006. Estimating hourly incoming solar radiation from limited meteorological data. Weed Sci. 54, 182-189.

Stape, J.L., Binkley, D., Ryan, M.G., 2004. Eucalyptus production and the supply, use and efficiency of use of water, light and nitrogen across a geographic gradient in Brazil. For.Ecol.Manage. 193, 17-31.

Stape, J.L., Binkley, D., Ryan, M.G., 2008. Production and carbon allocation in a clonal Eucalyptus plantation with water and nutrient manipulations. For.Ecol.Manage. 255, 920-930.

Stone, E.L., Kalisz, P.J., 1991. On the maximum extent of tree roots. For.Ecol.Manage. 46, 59-102.

Tamm, C.O., 1964. Determination of nutrient requirements of forest stands. Int.Rev.Forest Research 1, 115-170.

Tamm, C.O., 1991. Nitrogen in terrestrial ecosystems: Questions of productivty, vegetational changes, and ecosystem stability. Ecological Studies, 81. Springer-Verlag, Berlin Heidelberg New York. 115 p.

Trichet, P., Loustau, D., Lambrot, C., Linder, S., 2008. Manipulating nutrient and water availability in a maritime pine plantation: effects on growth, production, and biomass allocation at canopy closure. Ann.For.Sci. 65, 814-826.

USEPA. 2005. US Environmental Protection Agency - Metrics for expressing greenhouse gas emissions: Carbon equivalents and carbon dioxide equivalents. EPA420-F-05-002. Washington, DC. 
Vose, J.M., Allen, H.L., 1988. Leaf-area, stemwood growth, and nutrition relationships in loblolly-pine. For.Sci. 34, 547-563.

Wang, Y., Woodcock, C.E., Buermann, W., Stenberg, P.T., Voipio, P., Smolander, H., Hame, T., Tian, Y., Hu, J., Knyazikhin, Y., Myneni, R.B., 2004. Evaluation of the MODIS LAl algorithm at a coniferous forest site in Finland. Remote Sensing of Environment 91, 114-127.

Wang, Y.P., Jarvis, P.G., 1990. Description and validation of an array model - MAESTRO. Agric. For. Meteorol. 51, 157-180.

Waring, R.H., Landsberg, J.J., Williams, M., 1998. Net primary production of forests: a constant fraction of gross primary production? Tree Physiol. 18, 129-134.

Waring, R.H., Newman, K., Bell, J., 1981. Efficiency of tree crowns and stemwood production at different canopy leaf densities. Forestry 54, 129-137.

Waring, R.H., Running, S.W., 1998. Forest ecosystems. Academic Press, San Diego. 370 p.

Waring, R.H., Runyon, J., Goward, S.N., McCreight, R., Yoder, B., Ryan, M.G., 1993. Developing remote sensing techniques to estimate photosynthesis and annual forest growth across a steep climatic gradient in western Oregon, USA. In: Linder, S., Kellomaki, S. (Eds.), Management of structure and productivity of boreal and subalpine forests, Sweden, p. 94.

Will, R.E., Munger, G.T., Zhang, Y.J., Borders, B.E., 2002. Effects of annual fertilization and complete competition control on current annual increment, canopy development and growth efficiency of different aged Pinus taeda stands. Can.J.For.Res. 32, 1728-1740.

Woodbury, P.B., Smith, J.E., Heath, L.S., 2007. Carbon sequestration in the U.S. forest sector from 1990 to 2010. For.Ecol.Manage. 241, 14-27.

Zerpa, J.L., Fox, T.R., 2011. Controls of volatile ammonia losses from loblolly pine plantations fertilized with urea in the southeast USA. Soil Sci.Soc.Am.J. 75, 257-266. 
Highlights (for review)
Highlights
1. Light use efficiency (LUE) was not affected by site and treatment.
2. Stem, aboveground and total LUE were $1.21,1.51$, and $0.85 \mathrm{~g} \mathrm{MJ}^{-1}$, respectively.
3. Up to an additional $13.4 \mathrm{Mg} \mathrm{CO}_{2}$ equivalents $\mathrm{ha}^{-1} \mathrm{yr}^{-1}$ were stored with treatment.

Highlights (for review)
Highlights
1. Light use efficiency (LUE) was not affected by site and treatment.
2. Stem, aboveground and total LUE were $1.21,1.51$, and $0.85 \mathrm{~g} \mathrm{MJ}^{-1}$, respectively.
3. Up to an additional $13.4 \mathrm{Mg} \mathrm{CO}_{2}$ equivalents $\mathrm{ha}^{-1} \mathrm{yr}^{-1}$ were stored with treatment.

Highlights (for review)
Highlights
1. Light use efficiency (LUE) was not affected by site and treatment.
2. Stem, aboveground and total LUE were $1.21,1.51$, and $0.85 \mathrm{~g} \mathrm{MJ}^{-1}$, respectively.
3. Up to an additional $13.4 \mathrm{Mg} \mathrm{CO}_{2}$ equivalents $\mathrm{ha}^{-1} \mathrm{yr}^{-1}$ were stored with treatment.

Highlights (for review)
Highlights
1. Light use efficiency (LUE) was not affected by site and treatment.
2. Stem, aboveground and total LUE were $1.21,1.51$, and $0.85 \mathrm{~g} \mathrm{MJ}^{-1}$, respectively.
3. Up to an additional $13.4 \mathrm{Mg} \mathrm{CO}_{2}$ equivalents $\mathrm{ha}^{-1} \mathrm{yr}^{-1}$ were stored with treatment.

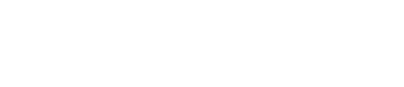

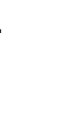

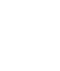

.

.

.
(2)

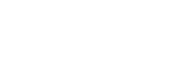




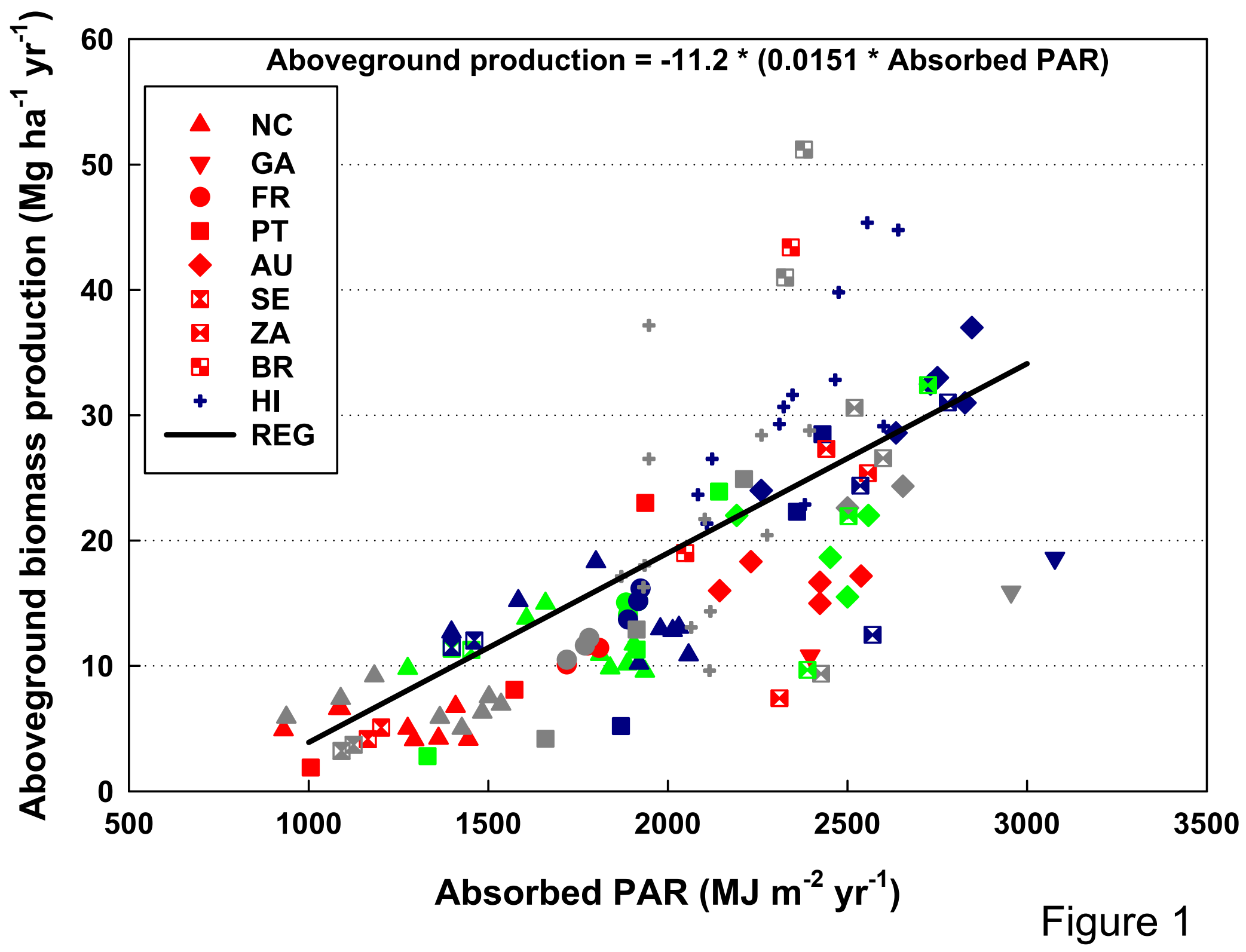




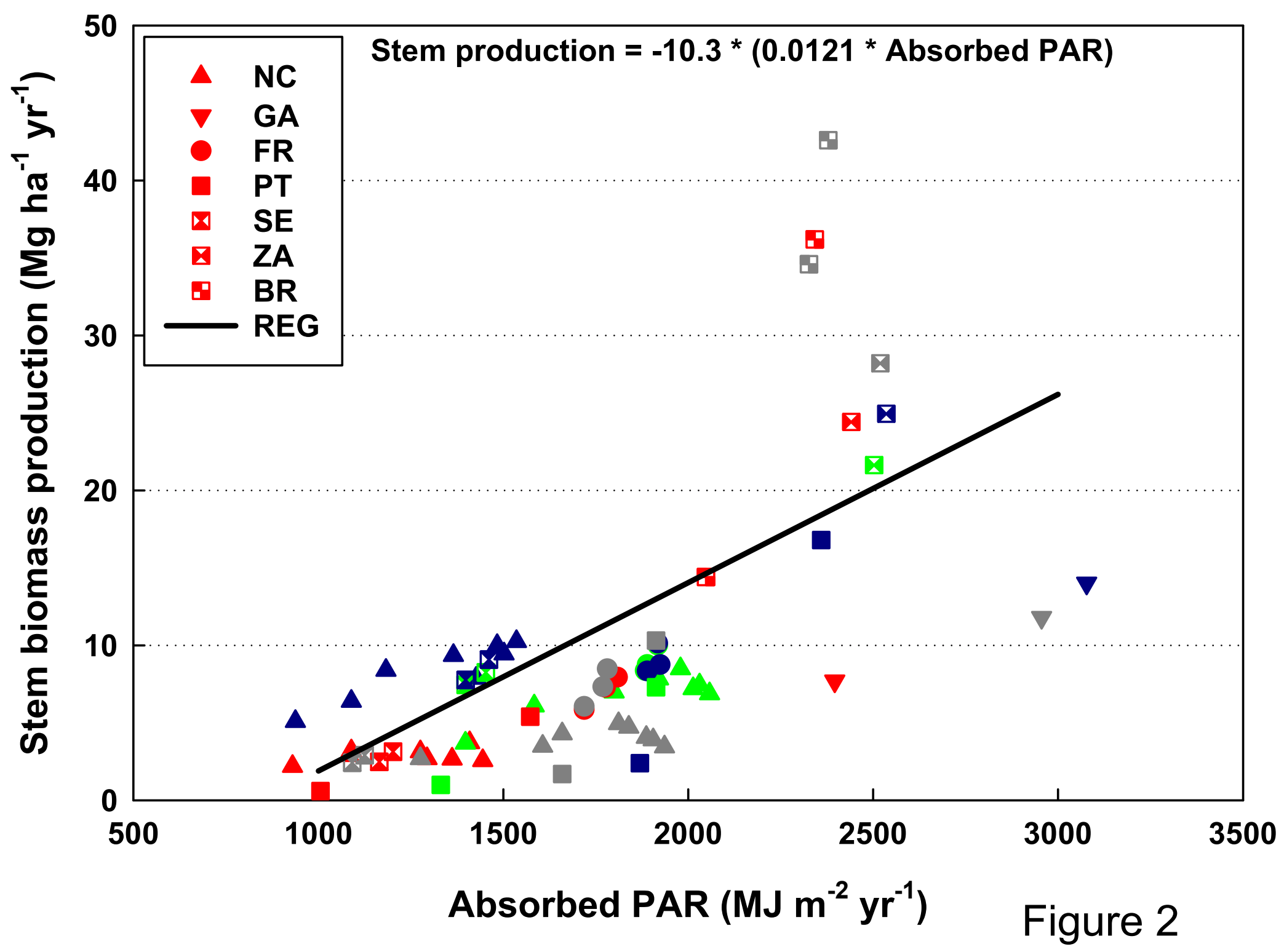


